\title{
Production and marketing constraints of fisherwomen self help groups in Thoothukudi District, Tamil Nadu
}

\author{
R. JAYARAMAN \\ Department of Fisheries Economics, Fisheries College and Research Institute, Tamil Nadu Fisheries University \\ Thoothukudi - 628 008, Tamil Nadu, India \\ e-mail:ramanrj@gmail.com
}

\begin{abstract}
A study was conducted to identify the constraints faced by fisherwomen self help groups (SHGs) especially with respect to production and marketing. A sample of 40 fisherwomen from the SHGs in Tharuvaikulam fishing village in Thoothukudi District of Tamil Nadu was selected randomly and the required data were collected using a pre-tested interview schedule in the year 2013. Garrett ranking technique was used to analyse the constraints ranked by the fisherwomen according to their perception of importance. Seven production constraints were identified and among them, high cost of inputs (raw material) was ranked first. They identified five financial constraints, of which lack of funds for starting and running business activities was the single most important constraint. Among the five constraints that influenced cohesion of the SHGs, lack of leadership and guidance affected the performance of the SHGs including their business activities. Among the 14 marketing constraints identified, lack of marketing skills was found the most important. With regard to performance constraints, it was observed that less profits brought down their performance. Among the six extension constraints that affected market access, lack of contact between producer and consumer was identified as most important. Lack of lateral thinking and innovation among the seven entrepreneurship constraints, was identified to deny them success in their business.
\end{abstract}

Keywords: Fisherwomen SHGs, Microfinance, Production and marketing constraints

Fisheries is a sunrise sector contributing ₹3,623 crores (about 1\%) to the GDP of Tamil Nadu at prevailing prices in 2011-12 (Tamil Nadu Statistical Handbook, 2013). The estimated fish production in the state was $6,11,489 \mathrm{t}$ comprising 4,26,735 $\mathrm{t}$ of marine fish $(69.79 \%)$ and $1,84,753 \mathrm{t}$ of inland fish $(30.21 \%)$. Tamil Nadu is a major producer of fish in the country which contribute to ensuring food and nutritional security of the protein starved people who eat predominately rice, particularly the rural populace. Further, it provides livelihood to 9.15 lakh fisherfolk who eke-out a living from fisheries. Exports of $80,715 \mathrm{t}$ of fish and fishery products earned ₹30,028.73 crores worth foreign exchange to the state exchequer in 2011-12.

The trends in the marine fish landings showed that it is export-demand driven, particularly for the high valued species like shrimps, lobsters, squids and cuttlefish. Slowly yet steadily, overcapitalisation set in leading to overfishing and catalysing its attendant adverse effects on the fisherfolk who depend on it for their livelihood as well as on the sustainability of the marine fishery resource itself. The marine fishery sector in the state is largely unregulated, open access, except for the 45 days ban imposed on the trawlers during April-May every year. Other regulatory measures such as time zoning, minimum mesh at the cod end, ban on pair trawling, purse seining and of threatened species remain more in books than in reality reflecting the scant respect the fisherfolk have for these regulatory measures.

Self help groups (SHGs) have been promoted as a vehicle of women empowerment covering social, economic, cultural and political dimensions. These SHGs undertake small economic enterprises to supplement family income as well as for availing benefits provided by the government. Earlier studies on fisherwomen SHGs have shown that the SHGs had been functioning extremely well with very prompt repayment of the microfinance availed from the banks (Jayaraman, 2000, 2002, 2005, 2008; Uwe and Lolita , 2003; Vipinkumar, 2012, 2013). The present study focused on the constraints faced by fisherwomen SHGs with emphasis on entrepreneurship and marketing aspects. The findings of the study will be helpful to formulate strategies for enabling the fisherwomen SHGs to undertake marketing more efficiently.

The study was conducted in the year 2013 in Tharuvaikulam Village in Thoothukudi District, a major marine fish landing centre in the State. The district is well known for the pearl fishery which was fully wiped out by the trawlers. A sample of 40 fisherwomen belonging to 
the SHGs in the village was selected randomly and the required data were collected using a pre-tested interview schedule. The fisherwomen were asked to rank the constraints faced by them according to their perception.

Garret ranking technique (Garrett and Woodworth, 1969) was used to analyse the constraints perceived by the fisherwomen. The respondents were asked to rank the reasons in the order of importance and these ranks were converted into percent position using the following formula:

Percent position $=\frac{100(R i j-0.05)}{N i j}$

where, $R i j$ is the rank given for $i^{\text {th }}$ item by $j^{\text {th }}$ individual and $N i j$ is the number of items ranked by the $j^{\text {th }}$ individual.

The percent position of each rank was converted into scores using Garrett's table. For each constraint, scores of individual respondents were added together and divided by total number of respondents for whom scores were added. Thus, mean score for each constraint was ranked by arranging them in descending order of importance.

The data on the various constraints reported by the fisherwomen SHG members in the establishment and operation of micro enterprises with focus on marketing of their produces in the study area were collected and analysed using the Garret ranking technique (Garrett and Woodworth, 1969).

Production constraints: Seven production constraints were identified by the respondents and among them high cost of inputs including that of finfish and shellfish was ranked first with a mean score of 70 (Table 1). This finding concurs with Jaya Varadhan et al. (2012) and Subhadra et al. (2009) who reported that the prime constraint in milk production is high cost of feed. Lack of adequate supply of raw material (finfish/shellfish), high transportation cost, production of similar or homologous products from other SHGs in the same location, lack

Table 1. Production constraints

\begin{tabular}{lll}
\hline Constraints & Mean score & Rank \\
\hline $\begin{array}{l}\text { High cost of the inputs including finfish } \\
\text { and shellfish }\end{array}$ & 70 & I \\
$\begin{array}{l}\text { Lack of adequate supply of fin fish/ } \\
\text { shellish }\end{array}$ & 59 & II \\
$\begin{array}{l}\text { High transportation cost } \\
\begin{array}{l}\text { Production of similar or homologous } \\
\text { products from other SHGs in the same }\end{array}\end{array}$ & 53 & III \\
$\begin{array}{l}\text { location } \\
\text { Lack of adequate knowledge about the } \\
\text { enterprise }\end{array}$ & 41 & IV \\
$\begin{array}{l}\text { Lack of insurance coverage } \\
\text { Lack of adequate supply of other inputs }\end{array}$ & 10 & V \\
\hline
\end{tabular}

of adequate knowledge about the enterprise, lack of insurance coverage and lack of adequate supply of other inputs were the other constraints in the order of importance with mean scores of 59, 53, 47, 41, 31 and 10 respectively.

Financial constraints: The fisherwomen generally agree that finance is always a major hurdle in their economic empowerment. They identified five financial constraints (Table 2). Lack of funds for starting and running the business activities was identified as the single most important financial constraint which got a mean score of 62. Other financial constraints in their order of priority were inadequate support from the bank officials, lack of funds, high interest rate for loans and declining profits and business sustainability which received mean scores of 55 , 43, 37 and 18 respectively. Results of the study agree with the findings of Kokate et al. (1988), Yadav et al. (1995) and Jithendran et al. (1998).

Table 2. Financial constraints

\begin{tabular}{lll}
\hline Constraints & Mean score & Rank \\
\hline Lack of funds & 62 & I \\
$\begin{array}{l}\text { Inordinate delay in obtaining loan from } \\
\text { banks }\end{array}$ & 55 & II \\
$\begin{array}{l}\text { Declining profits and business } \\
\text { sustainability }\end{array}$ & 43 & III \\
$\begin{array}{l}\text { High interest rate for the loan } \\
\begin{array}{l}\text { Inadequate support from the bank } \\
\text { officials }\end{array}\end{array}$ & 37 & IV \\
\hline
\end{tabular}

Cohesion of the SHGs: Successful functioning of the SHGs depend to a large extent on the cohesion of the SHGs. The respondents thought lack of leadership and guidance affected performance of the SHGs including their business activities. This constraint got a mean score of 69 (Table 3). Lack of federation for the SHGs, lack of encouragement from fellow members, lack of leadership and guidance and reduction in members strength due to marriage, relocation etc. were ranked successively which got mean scores of 58, 50, 40 and 24 respectively.

Marketing constraints: Next to credit, all producers, be it fish farmers or fisherfolk reported access to markets and marketing hurdles as their major problems. Some products with innovation in production efforts can be marketed easily and for others it involves huge marketing and product promotion expenses. In this study also, the fisherwomen reported lack of marketing skills as the single most important marketing constraint which received a mean score of 82 (Table 4).

Other marketing constraints reported are lack of adequate price for the products, high marketing cost, high packaging cost, lack of remunerative price, un-organised producers in marketing similar products, distant markets, competition among fellow SHGs in the same village, lack 
Table 3. Cohesion of the SHGs

\begin{tabular}{lll}
\hline Constraints & Mean score & Rank \\
\hline Lack of leadership and guidance & 69 & I \\
Lack of federation for the SHGs & 58 & II \\
$\begin{array}{l}\text { Lack of encouragement from fellow } \\
\text { members }\end{array}$ & 50 & III \\
$\begin{array}{l}\text { Lack of support from other SHG members } \\
\text { Reduction in members strength due to }\end{array}$ & 40 & IV \\
marriage, relocation etc. & 24 & V \\
\hline
\end{tabular}

Table 4. Marketing constraints

\begin{tabular}{lll}
\hline Constraints & Mean score & Rank \\
\hline Lack of marketing skills & 82 & I \\
Lack of adequate price for the products & 76 & II \\
High marketing cost & 68 & III \\
High packaging cost & 64 & IV \\
$\begin{array}{l}\text { Middlemen not providing remunerative } \\
\text { price }\end{array}$ & 58 & V \\
$\begin{array}{l}\text { Unorganised producers in marketing } \\
\text { similar products }\end{array}$ & 56 & VI \\
$\begin{array}{l}\text { Distant markets } \\
\text { Competition among fellow SHGs in the }\end{array}$ & 52 & VII \\
same village & 48 & VIII \\
Lack of government support in marketing & 44 & \\
the product & & IX \\
Lack of consumer support & 41 & X \\
Lack of quality & 36 & XI \\
Lack of advertisement & 33 & XII \\
High quality control testing charge & 25 & XIII \\
Lack of marketing infrastructure & 20 & XIV \\
\hline
\end{tabular}

of government support in marketing the product, lack of consumer support, lack of quality, lack of advertisement, high quality control testing charges and lack of marketing infrastructure with mean scores of $76,68,64,58,56,52$, $48,44,41,36,33,25$ and 20 respectively.

In agriculture, farmers have been complaining that the cost of production of farm products like rice has been increasing at alarming levels while price of the product has not risen proportionately. The fisherwomen also reported lack of adequate price as the second important constraint.

High marketing costs could prove to be disastrous in the long run. The respondents felt this as a serious problem. Similarly, another relevant problem identified was high packaging cost. The fisherwomen are organised as SHGs but when it comes to marketing, they don't deal with organised market institutions. Generally, they have to reach the consumers through middlemen who charge a high commission for linking them with the consumers.

Products of SHGs do not enjoy wide consumer acceptance to the level of products marketed by established manufacturers. Popular brands command high price in the market because the consumers perceive them to be of high quality. The SHGs have not been very successful in creating a brand name for their products. Lack of quality standards and certification constrained the fisherwomen in marketing their products effectively as reported by earlier workers (Kokate et al., 1988; Yadhav et al., 1995; Jithendranathan et al., 1998; Mishra, 1999; Singh, 2000; Jha, 2002; Meganathan, 2010; Meganathan et al., 2011).

Performance constraints: The performance of an organisation depends on several factors. Fisherwomen identified that less profits brought down their performance and this constraint received a mean score of 75 (Table 5). This was closely followed by other constraints such as difficulty in scaling up business, difficulty in linking with marketing agencies, lack of fair price for the product, lack of marketing information, lack of marketing support from government offices, lack of funds, lack of mobility, family ties, lack of time and lack of education which obtained mean scores of 70, 65, 59, 56, 51, 46, 42, 35, 29 and 19 respectively. Similar findings have been reported by Rao (1999), Tatti (1999), Reji (2002) and Anand (2004).

Table 5. Performance constraints

\begin{tabular}{lll}
\hline Constraints & Mean score & Rank \\
\hline Less profits & 75 & I \\
$\begin{array}{l}\text { Difficulty in scaling up business } \\
\text { Difficulty in linking with marketing } \\
\text { agencies }\end{array}$ & 70 & II \\
Lack of fair price for the product & 59 & III \\
Lack of marketing information & 56 & IV \\
$\begin{array}{l}\text { Lack of marketing support from } \\
\text { government offices }\end{array}$ & 51 & V \\
Lack of funds & 46 & VI \\
Lack of mobility & 42 & VII \\
Family ties & 35 & VIII \\
Lack of time & 29 & IX \\
Lack of education & 19 & X \\
\end{tabular}

Extension constraints affecting market access: Access to the market is influenced by many factors. One may be good in successful production and another could be good in successful marketing. Everybody cannot be equally successful in production as well as in marketing. Hence, some manufacturers engage reputed marketing institutions for marketing their products. Fisherwomen in the study area identified lack of contact between producer and consumer as the most important constraint that affected market access. This factor got a mean score of 69 (Table 6). This was closely followed by another similar constraint i.e., lack of contact between producer and marketing agency, which got a mean score of 62 . Other constraints are lack of contact between producer and educational as well as research institutes, lack of adequate training in production, lack of contact with NGOs and lack of extension programmes for the SHG women, which obtained mean scores of 52, 46, 40 and 30 respectively. 
Table 6. Extension constraints

\begin{tabular}{lll}
\hline Constraints & Mean score & Rank \\
\hline $\begin{array}{l}\text { Lack of contact between producer and } \\
\text { consumer }\end{array}$ & 69 & I \\
$\begin{array}{l}\text { Lack of contact between producer and } \\
\text { marketing agency }\end{array}$ & 62 & II \\
$\begin{array}{l}\text { Lack of contact between producer and } \\
\text { educational/research institutes }\end{array}$ & 52 & III \\
$\begin{array}{l}\text { Lack of adequate training in production } \\
\text { Lack of contact with NGOs }\end{array}$ & 46 & IV \\
$\begin{array}{l}\text { Lack of extension educational } \\
\text { programmes for SHG women }\end{array}$ & 40 & V \\
\end{tabular}

These findings concur with those of the earlier studies by Jayalakshmi (2001), Lina Joy and Krishnan (2008), Mehta (1999) and Sarada (2001).

Entrepreneurship constraints: Lack of lateral thinking and innovation was reported by the fisherwomen as a major constraint to achieve success in their business. This constraint got a mean score of 78 (Table 7). Lack of determination, lack of positive attitude, lack of entrepreneurship skills, lack of risk bearing ability, lack of ability to diversify production and lack of communication skills are the other constraints identified which got mean scores of 66, 57, 50, 42, 34 and 22 respectively.

The fisherwomen have been struggling with a myriad of constraints which belong to the domains of technical, financial, organisational and policy realms. Addressing these constraints will certainly enable the fisherwomen to produce and market their products more efficiently and improve their livelihood. India is having the largest microfinance program globally. Technology generating institutions like universities could help the fisherwomen acquire production, marketing and managerial or organisational skills through capacity building programs. The National Bank for Agriculture and Rural Development (NABARD) is the nodal agency for microfinance in agriculture and allied activities in the country and it has been playing an exemplary role in empowering the poor through microfinance. The fisherwomen SHGs could avail the services of the development institutions including the NGOs in empowering themselves through successful business.

Table 7. Entrepreneurship constraints

\begin{tabular}{lll}
\hline Constraints & Mean score & Rank \\
\hline Lack of lateral thinking and innovation & 78 & I \\
Lack of determination & 66 & II \\
Lack of positive attitude & 57 & III \\
Lack of entrepreneurship skills & 50 & IV \\
Lack of risk bearing ability & 42 & V \\
Lack of ability to diversify production & 34 & VI \\
Lack of communication skills & 22 & VII \\
\hline
\end{tabular}

\section{References}

Anand, J. S. 2004. Self help groups in empowering poor women: Some experience from Kerala, India. In: Menon, V., Nair, P. G. and Nair, K. N. (Eds.), Alleviating poverty: Case studies of local level linkages and processing in developing world. Rainbow Publishers, Noida, India, p. 285-309.

Garret, H. E. and Woodworth 1969. Statistics in psychology and education. Vakils, Feffer and Simons Pvt. Ltd., Mumbai, $329 \mathrm{pp}$

Jayalakshmi, G. 2001. Empowering of rural women through self help groups - An action research. Ph. D. thesis, Kerala Agricultural University, Thrissur.

Jayaraman, R. 2000. Role of self help groups in fisherwomen development in India. Fourth International Conference of the Coastal Zone Canada Association, 17 - 21 September 2000, Saint John, NB, Canada.

Jayaraman, R. 2002. Performance of self help groups in fisherwomen development in India. Coastal Zone Asia Pacific Conference, 12 - 16 May, 2002, Bangkok, Thailand

Jayaraman, R. 2005. Performance analysis of fisherwomen self help groups in Tamil Nadu, National Bank for Agriculture and Rural Development, Mumbai, 63 pp.

Jayaraman, R. 2008. Performance analysis of fisherwomen self help groups. Tamil Nadu J. Vet. Anim. Sci., 4(2): 52-55.

JayaVaradhan, B., Prabhu, M., Serma Saravana Pandiyan, A., Senthilkumar, G. and Selvakumar, K. N. 2012. Production and marketing constraints in dairy cattle rearing as perceived by women self help groups and non-members, Tamil Nadu J. Vet. Anim. Sci., 8(2): 68-71.

Jithendran, P., Sharma, O. P., Dawra, R. K., Makkar, H. P. S. and Singh, B. 1998. Survey of animal husbandry practices, bottlenecks in animal production and strategies for improvement: A profile of selected villages in Himachal Pradesh. Envis Bulletin, 6(2): 24-29.

Jha, A. K. 2002. Prioritisation of constraints in dairy milk production: A case study. Agric. Econ. Res. Rev., Conference Issue, 120-130.

Kokate, K. D., Tyagi, K. C. and Rao, S. V. N. 1988. Factors affecting feeding gaps in local cattle of tribal scenario. J. Rural Dev., 7(6): 709-721.

Lina Joy, A., Prema and Krishnan, S. 2008. Determinants of group performance of women-led agro-processing self help groups in Kerala. Agric. Econ. Res. Rev., 21: 355-362.

Meganathan, M. 2010. Constraint analysis of tribal livestock farming in Tamil Nadu. Tamil Nadu J. Vet. Anim. Sci., 6(1): 12-18.

Meganathan, M. 2011. Role of microfinance on urban self help groups: a micro study - Puducherry. J. Banking Fin. Services Insurance Res., 1(5).

Mehta, G. S. 1999. Development of Uttarakhand: Issues and perspectives. APH Publishing Corporation, New Delhi. 
Mishra, J. P. 1999. Agricultural marketing in tribal areas. The Bihar J. Agric. Marketing, 7(2): 133-139.

Rao, M. K. 1999. Organising and implementing income generating activities though self help groups in fisheries and agriculture, National Bank for Agriculture and Rural Development, Bangalore, $350 \mathrm{pp}$.

Reji, E. M. 2002. Impact of microfinance through SHGs in Malappuram District. M. Sc. (Ag.) thesis, Kerala Agricultural University, Thrissur.

Sarada, O. 2001. Empowerment of rural women through SHGs in Prakasam District of Andhra Pradesh - An analysis. M. Sc. (Ag.) thesis, University of Agricultural Sciences, Bangalore.

Subhadra, M. R., Suresh, K. A. and George, P. R. 2009. Constraint analysis of farmers operating mixed farming in Kerala, Agric. Sci. Digest, 29(1): 48-49.

Singh, J. P. 2000. An econometric analysis of factors influencing milk production and supply response of milk to change in price at producer's level: A study in Ranga Reddy District, Andhra Pradesh. Manage Ext. Res. Rev., 1(1): 112-118.
Tamil Nadu Statistical Handbook 2013. Department of economics and statistics, Government of Tamil Nadu, Chennai.

Tatti, I. 1999. General monitoring study of SHGs promoted by selected NGOs, Vijaya Bank Head Office, Bangalore, $80 \mathrm{pp}$.

Vipinkumar, V. P., Johnson, B., Swathilekshmi, P. S. and Ramachandran, C. 2013. Coastal rural indebtedness and its impact in marine fisheries sector of Tamil Nadu. J. Mar. Biol. Ass. India 55(1): 79-85.

Vipinkumar, V. P., Shyam. S. Salim, Narayanakumar, R., Sathiadhas, R., Madan, M. S., Ramachandran, C., Swathilekshmi, P. S. and Johnson, B. 2012. Coastal rural indebtedness and impact of microfinance in marine fisheries sector, Central Marine Fisheries Research Institute, Kochi, $138 \mathrm{pp}$.

Uwe Tietze and Lolita V. Villareal 2003. Microfinance in fisheries and aquaculture, guidelines and case studies, FAO Fishries Technical Paper 440, Rome, Italy.

Yadav, D. B., Mali, S. L. and Patil, B. R. 1995. Constraints of dairy enterprise. Indian. J. Agric. Econ., 50(3): 355. 